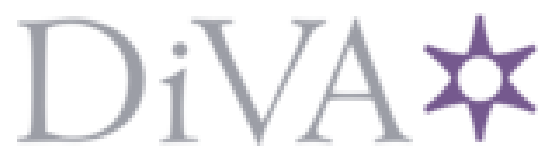

http://www.diva-portal.org

This is the published version of a paper published in $\operatorname{ReCALL}$.

Citation for the original published paper (version of record):

Sylvén, L., Sundqvist, P. (2012)

Gaming as extramural English L2 learning and L2 proficiency among young learners.

$\operatorname{ReCALL,~24(3):~302-321~}$

http://dx.doi.org/10.1017/S095834401200016X

Access to the published version may require subscription.

N.B. When citing this work, cite the original published paper.

Permanent link to this version:

http://urn.kb.se/resolve?urn=urn:nbn:se:kau:diva-12689 


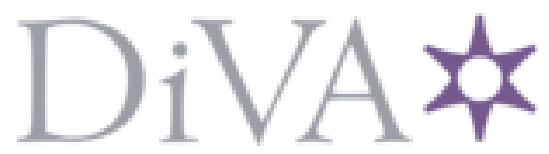

http://www.diva-portal.org

This is the published version of a paper published in $\operatorname{ReCALL}$.

Citation for the original published paper (version of record):

Sylvén, L., Sundqvist, P. (2012)

Gaming as extramural English L2 learning and L2 proficiency among young learners.

$\operatorname{ReCALL,~24(3):~302-321~}$

http://dx.doi.org/10.1017/S095834401200016X

Access to the published version may require subscription.

N.B. When citing this work, cite the original published paper.

Permanent link to this version:

http://urn.kb.se/resolve?urn=urn:nbn:se:kau:diva-12689 


\section{ReCALL}

http://journals.cambridge.org/REC

Additional services for $\operatorname{Re} C A L L$ :

Email alerts: $\underline{\text { Click here }}$

Subscriptions: Click here

Commercial reprints: Click here

Terms of use : $\underline{\text { Click here }}$

\section{Gaming as extramural English L2 learning and L2 proficiency among young learners}

Liss Kerstin Sylvén and Pia Sundqvist

ReCALL / Volume 24 / Issue 03 / September 2012, pp 302 - 321

DOI: 10.1017/S095834401200016X, Published online:

Link to this article: http://journals.cambridge.org/abstract_S095834401200016X

How to cite this article:

Liss Kerstin Sylvén and Pia Sundqvist (2012). Gaming as extramural English L2 learning and L2 proficiency among young learners. ReCALL, 24, pp 302-321 doi:10.1017/S095834401200016X

Request Permissions : $\underline{\text { Click here }}$ 


\title{
Gaming as extramural English L2 learning and L2 proficiency among young learners*
}

\author{
LISS KERSTIN SYLVÉN \\ Department of Education and Special Education, Faculty of Education, \\ University of Gothenburg, P O Box 300, SE-40530 Göteborg, Sweden \\ (email: lisskerstin.sylven@ped.gu.se) \\ PIA SUNDQVIST \\ Department of Languages - English, Faculty of Arts and Education, \\ Karlstad University, SE-65188 Karlstad, Sweden \\ (email: pia.sundqvist@kau.se)
}

\begin{abstract}
Today, playing digital games is an important part of many young people's everyday lives. Claims have been made that certain games, in particular massively multiplayer online role-playing games (MMORPGs) provide L2 English learners with a linguistically rich and cognitively challenging virtual environment that may be conducive to L2 learning, as learners get ample opportunities for L2 input and scaffolded interaction in the L2. In this paper, we present empirical evidence that L2 English proficiency correlates with the frequency of gaming and types of games played. We base our observation on a study among young L2 English learners ( $=86$, aged 11-12, Sweden). Data were collected through a questionnaire, a language diary, and three proficiency tests. The questionnaire provided demographic background information but was also targeted at measuring extramural English habits, i.e., learners' out-of-school contact with English (cf. Sundqvist, 2009). The diary measured how much time the learners spent on seven predetermined extramural English activities during one week, while the tests measured their achieved L2 proficiency regarding reading and listening comprehension, and vocabulary. Previous research among learners aged 15-16 (Sundqvist, 2009) showed positive correlations between playing digital games and L2 proficiency, in particular with regard to vocabulary, and also identified gender-related differences regarding vocabulary (boys outperformed girls) as well as the frequency of gaming and types of games played. These results were corroborated in the present study. A clear pattern emerged from our data: frequent gamers ( $\geq 5$ hours/week) outperformed moderate gamers who, in turn, outperformed non-gamers. Background variables could not explain the between-group differences. Even though the boys might have been more proficient or apt than the girls a priori and, therefore, chose to engage more in L2 gaming, the findings suggest that playing digital games at an early age can be important for L2 acquisition.
\end{abstract}

Keywords: digital games, extramural English, 12 proficiency, second language acquisition, motivation, incidental vocabulary acquisition

\footnotetext{
Our study was funded by grants from the Erik Wellander Foundation and the Center for Language and Literature in Education, Karlstad University, Sweden.
} 


\section{Introduction}

Playing digital games entails entering unknown territories, taking on new roles, learning new game rules and, for many players, doing all of the above in a second or foreign language. The situation is far from what students encounter in the language classroom where the teacher generally has the initiative; digital games (i.e., games played on computers as well as games played on game platforms) are played by choice and at the individual's own initiative. In this article we will empirically show that out-of-classroom digital gaming among young learners in Sweden correlates positively with their English vocabulary knowledge and receptive proficiency measured in school. Even though we cannot provide any evidence that these learning gains can be attributed to the leisure activity of gaming, we presuppose that linguistically rich and cognitively challenging digital games contain relevant second language (L2) input and stimulate scaffolded interaction between players, thus supporting the development of L2 proficiency. ${ }^{1}$

In what follows, we first give a brief background on gaming as extramural English L2 learning. Then we provide a theoretical overview of how digital games might support L2 learning, and state our research questions. After that we describe the study and discuss our research findings. The article ends with some suggestions for future research in the area of digital gaming and L2 learning.

\section{Background: gaming as extramural English L2 learning}

Commonly, L2 learning takes place within a classroom, but when the L2 is a global language such as English, it also occurs to a large extent outside of school, at least in Sweden (Olsson, 2011; Sundqvist, 2009; Sundqvist \& Sylvén, 2012; Sylvén, 2004) and most likely also in countries with comparable educational systems and socio-economic prosperity, such as Finland (cf. Forsman, 2004), Belgium (cf. Kuppens, 2010), and the Netherlands (cf. Persson, 2011). Spare time activities are for the most part chosen by the individuals themselves, and the motivation to perform well in such activities is therefore likely to be high. As is widely agreed upon, motivation is necessary for any learning to take place, and in particular for learning an L2 (Dörnyei, 2001).

Even though playing digital games is commonly viewed as a typical activity for teenagers, it is in fact popular among people of all ages (Gee, 2007). Statistics for the year 2008 from the European Union show that it is fairly common among EU citizens aged 16-74 (i.e., "all ages") to download computer games, which they presumably also play once downloaded (European Commission, 2012). Furthermore, people worldwide enjoy playing digital games in their free time, such as in the US (The Entertainment Software Association, 2012), Japan (Wyman, 2006), and Sweden (Medierådet, 2010) ${ }^{2}$.

Moreover, the default language of interaction and communication in many game environments is English (Stenberg, 2011; Waters, 2007). For anybody with L2 English this constitutes a challenge. In order to be able to play these games, the L2 linguistic input must be understood and, therefore, it is not a far-fetched hypothesis

1 In the following, the term $L 2$ is used for both second and foreign languages.

2 Medierådet is the Swedish Media Council. 
that successful and frequent players of such games who do not have English as their mother tongue acquire some of their English L2 proficiency in the activity of gaming.

In a study focusing the effect of content and language integrated learning (CLIL) on incidental vocabulary acquisition, Sylvén (2004) found that rather than the CLIL approach per se, it was the engagement in English activities outside of school, "extramural English activities" (Sundqvist, 2009:25), that showed significant correlations with a richer vocabulary. Similarly, Sundqvist (2009) found that extramural English correlated significantly with ninth graders' vocabulary size and with their level of oral proficiency (cf. Forsman, 2004). Further, Sundqvist concludes that digital gaming along with reading and using the Internet were more conducive to L2 learning than other activities, such as listening to music or watching TV or films. Piirainen-Marsh and Tainio (2009) investigated two 13-year-old boys playing Final Fantasy $X$ (a role-playing game) in their homes and argued that the boys, in their narrative repetitions of in-game events, displayed particular usages of English that might be indicative of L2 development.

Another finding in the Sundqvist (2009) study was that the boys preferred to play massively multiplayer online role-playing games (MMORPGs), whereas the girls opted for offline single-player games such as The Sims. In the same vein, Greenberg, Sherry, Lachlan, Lucas, and Holmstrom (2010) found that the young teenage boys in their study favored what is referred to as "physically oriented video games", like MMORPGs. Furthermore, it was clear that the girls chose more "traditional, thoughtful games", of which The Sims might be an example. Distinguishing between multi- and single-player games is one way to characterize digital games, but there is no consensus in the game design community regarding the characterization or description of games (Dickey, 2006). For the purpose of analysis it is useful, however, to have a framework for types of game. Kinzie and Joseph (2008), for example, suggest the use of six activity modes to describe types of game play: Active, Explorative, Problemsolving, Strategic, Social, and Creative play. Commercial digital games, which compared to educational games are played more as a pastime (Medierådet, 2010), are typically thought of in relation with Active play, but also with other modes. Typical Active play games are "shooter" (e.g., Counter-Strike) and arcade-style games (e.g., Grand Theft $A u t o$ ), that is, games that require players to be active in one way or another. Unfortunately, Kinzie and Joseph (2008) do not provide game titles for each activity mode but the offline single-player simulation game The Sims is said to include the Strategic and Creative modes. Thus, The Sims provides opportunities to simulate virtual worlds, including creating the environment, such as building cities and houses, as well as taking care of the inhabitants (the Sims, as the in-game characters are known). Players then engage interactively in the virtual lives of the Sims. In comparison, many MMORPGs include several modes of game play and the currently predominant MMORPG World of Warcraft $(W o W)$ includes all six.

In sum, research indicates that there might be a connection between digital gaming and L2 learning. Furthermore, the different types of digital games available seem to offer language learning contexts of various kinds. In this study, we intend to dig deeper into extramural English learning with games, and want to ascertain whether the playing of different games is associated with differences in L2 proficiency. Therefore, we focus on two broad categories of commercial games, as also evidenced by differences in game 
preferences between boys and girls, namely MMORPGs, such as $W o W$, on the one hand and offline single-player games, such as The Sims, on the other. In what follows, we will discuss these games and their affordances for language learning on the basis of factors deemed critical in second language acquisition (SLA).

\section{L2 learning in digital games: theoretical overview and formulation of research questions}

In recent years, game-based learning in general has received much attention, but this field of inquiry can still be said to be in its infancy (Spector \& Ross, 2008). Digital gaming as a potential arena for language learning in particular has also been in focus (see, e.g., deHaan, Reed, \& Kuwada, 2010; Gee, 2007; Piirainen-Marsh \& Tainio, 2009; Rankin, Gold, \& Gooch, 2006; Thorne, Black, \& Sykes, 2009). When studying gaming from an L2 English learning perspective it soon becomes evident that certain games offer circumstances that are in SLA theory considered important for L2 learning: first, comprehensible input and scaffolding through interaction, and second, motivation.

In the SLA literature it is uncontested that comprehensible target language input and scaffolding through interaction are necessary conditions for L2 development. As is well known, Krashen's (1982) Input Hypothesis states that acquisition takes place as long as learners are exposed to comprehensible input one step beyond their present stage of linguistic competence. In line with this, current thinking inspired by sociocultural theory (SCT) emphasizes the need for input at a level that ideally falls within the learner's zone of proximal development (ZPD), i.e., the distance between the learner's actual and potential developmental levels. SCT stresses the role of the L2 environment, in particular learners' reliance on adult guidance and interaction with more capable peers (see, e.g., Lantolf \& Thorne, 2008). More recently the term scaffolding, which accords with Vygotsky's (1978) ZPD and was originally introduced by Wood, Bruner, and Ross (1976), has been emphasized as a crucial factor in the language learning process (Hammond \& Gibbons, 2001).

Taking a more cognitive perspective, Long's (1981) Interaction Hypothesis views the interplay between L2 input, learners' output and the feedback learners receive on their production as pivotal for L2 development. Through such interaction, supposedly, the learner is able to acquire new features of the L2 thanks to instances of negotiation of meaning and episodic attention to form. Ellis (1984:95), then, argues that interaction is "the means by which the learner is able to crack the code". Consequently, several scholars have emphasized the need to provide opportunities for learners to produce output in interaction in order to master the target language at a higher level than mere receptive understanding (Gass \& Mackey, 2006; Swain, 1995). Swain's (2000) notion of collaborative dialogue is one potential way of meeting that need.

In the game-based language learning literature, it has been noted and empirically observed that collaborative dialogues prevail in a digital game such as $W o W$, where many tasks require collaboration. Stenberg (2011) clarifies that most dialogic communication in $W o W$ is done in writing using various chats and game forums but that simultaneously - voice chat is not unusual either, particularly with specific game friends (see also Wirman, 2007 for frequent gamers' use of forums). Harteveld and 
Bekebrede (2011) highlight this social dimension of WoW (see also Schrader \& McCreery, 2008) where, for instance, experienced players are expected to help newcomers advance in the game. The interaction and collaboration going on in MMORPGs might certainly be cognitively demanding, especially when players use their L2, fostering what Steinkuehler and Duncan (2008:531) refer to as "scientific habits of mind", that is, the ability to, for instance, build on others' ideas, use counter-arguments, and understand feedback. Thorne (2008) observes explicit attention to linguistic form in repair sequences during WoW interactions. Further, Reinders and Wattana (2010) observe positive effects of playing multiplayer games on the quantity and quality of L2 interaction and on learners' willingness to communicate. In addition, Gee (2007:67) argues that good digital games force a player/ learner to "operate within, but at the outer edge of, the learner's resources". Thus, learners are challenged yet find the game tasks doable, which in turn develops their language skills. Gee refers to this as the Regime of Competence Principle and we would like to emphasize its similarity to Vygotsky's ZPD. In a single-player game such as The Sims, opportunities for inter-player interaction and need for output are rarer and not necessarily inherent properties of the game (cf. Sundqvist \& Sylvén, 2012). Consequently, in comparison with MMORPGs, such games are more restricted as potential L2 learning arenas.

Knowledge of vocabulary, undoubtedly a fundamental aspect of L2 proficiency (N. Ellis, 1994; R.Ellis, 1999; Laufer, 1998), can be acquired either intentionally or incidentally. Whereas the former refers to the learning of vocabulary with the learner's explicit intent of doing so, the latter refers to "the learning without an intent to learn, or as the learning of one thing, e.g. vocabulary, when the learner's primary objective is to do something else, e.g. to communicate" (Laufer \& Hulstijn, 2001:10; cf. also Schmidt, 1994); that is, vocabulary learning is a by-product of another learning activity. Several ways have been suggested to stimulate incidental vocabulary learning, such as extensive reading (see, e.g., Cho \& Krashen, 1994; Nation, 2001) and problem-solving group work activities (Joe, 1996). And, as mentioned above, playing digital games with rich L2 input may also be a possible path for learners to improve their L2 vocabulary incidentally (cf. Sundqvist, 2011).

Regarding L2 vocabulary acquisition, scholars have suggested that knowledge of between 2,000 and 3,000 words enables the understanding of approximately $80 \%$ of written texts (Laufer, 1992; Nation \& Waring, 1997). This threshold level of vocabulary proficiency allows learners to deduce the meaning of unknown words from the context and through negotiation of meaning with teachers or peers, thus adding new words to their mental lexicon. The larger an individual's L2 lexicon, the higher the potential benefits of the ZPD for vocabulary learning. In gaming environments, learners may learn the meaning of new lexical items from the gaming context or by asking co-players, in other words, through interaction, provided that learners have reached the threshold level of vocabulary proficiency.

In an early study involving gaming and incidental L2 vocabulary learning, Cheung and Harrison (1992) showed that intensive game-work enabled the participants to improve in terms of game-specific lexical items. Further, Miller and Hegelheimer (2006) as well as Ranalli (2008) study the effects of supplementing The Sims with material to make the vocabulary input more comprehensible, both with positive results. In a study of the 
MMORPG EverQuest 2, it was found that five intermediate and advanced L2 English students increased their vocabulary considerably (Rankin, Gold \& Gooch, 2006).

It should be stressed that these studies focus on adults, and that few studies have involved young learners. Turgut and Irgin (2009) studied children playing digital games in English at Internet cafés. From a phenomenological perspective, they argue that digital gaming allows players to incidentally make use of vocabulary "for their own purposes, in complex and pleasurable ways" (op. cit., 761). A second study with young learners examined intentional vocabulary learning with a specially designed vocabulary training program in the form of a digital game (Cobb \& Horst, 2011). They investigated 50 Francophone English L2 learners in Canada, 12 to 13 years old, and found that longer periods of game play are needed to consolidate learning.

Another study among young learners (Kinzie \& Joseph, 2008) surveys middle school (grades 6-8) children's preferences among the six activity play modes mentioned above. Even though L2 vocabulary acquisition was not in focus in that study, it is worth mentioning that already among children this young there were statistically significant between-gender differences for four of these play modes: the boys generally preferred Active and Strategic play, while the girls opted in favor of Creative and Explorative modes. Kuppens (2010) investigates the influence of media, such as subtitled English TV-programs and movies, music and computer games on young (age 11) learners' oral translation skills. She found, among other things, a significant gender difference in the types of media preferred, where the boys played more English-language computer games and visited more English websites than the girls. There was a positive correlation between translation skills and playing computer games. However, this correlation was not very strong, which was attributed to the fact that no distinction was made between different types of games (Kuppens, 2010).

Having outlined the hypothesized and observed benefits of comprehensible input and scaffolding through interaction on general L2 proficiency and vocabulary acquisition specifically, we now turn to the second factor which we consider crucial in connection with digital gaming and L2 learning, namely motivation. Dörnyei (2001) views motivation as pivotal for language learning. He argues that it is the ideal L2 self that decides the level of motivation for a certain task (Dörnyei, 2009). In the context of digital gaming, this ideal L2 self can be translated into a player's wish and readiness to take on the role of an avatar, envisioning him- /herself ideally performing it (cf. Harteveld \& Bekebrede, 2011). There is some empirical evidence for the validity of such claims. For instance, Yee and Bailenson (2007) introduce the so-called Proteus Effect, which deals with how players' behavior conforms to their digital self-representation independently of how others perceive them. They found that gamers who were assigned taller avatars in a negotiation task showed greater confidence than those who used shorter avatars. Moreover, Gee (2007:63) argues convincingly that the "projective identity is the space in which the learner can transcend the limitations both of the virtual identity and the learner's own real-world identity". In other words, one's choice of avatar seems to affect behavior in game play: an avatar can function as a mask behind which an individual can act in ways he/she otherwise perhaps would not. Thus, new possibilities are supposedly offered regarding one's use of language and behavior (Stenberg, 2011), even though young players do not necessarily create avatars much different from themselves 
(Kinzie \& Joseph, 2008). From an L2 learning perspective, the gamer can be said to aim for his/her ideal L2 self within the gaming environment.

Summing up, the limited amount of research shows that digital games provide fertile ground for L2 acquisition. Great possibilities for target language input, output, and interaction are offered, especially in MMORPGs. Digital games are to a large extent perceived as authentic and the players/learners are highly motivated to continue playing (cf. Gee, 2007; Stenberg, 2011; Thorne, et al., 2009). Since playing games as a spare time activity is highly volitional, we consider the number of hours L2 learners spend playing indicative of their motivation.

Although this theoretical overview points at the inherent potential of L2 learning in digital gaming, empirical studies focused on young learners' game habits and L2 proficiency are scarce. In the following, we present a study that at least partially attempts to fill that void in research. We investigated the relationship between extramural English and L2 proficiency among young learners. The research questions were:

1. Is there a positive correlation between learners' L2 proficiency and their engagement in extramural English activities in their spare time (i.e., time spent playing)?

2. Are there gender differences regarding the learners' (a) engagement in extramural English activities and (b) L2 proficiency?

\section{Methodology and results}

\subsection{Sample and materials}

The data were collected as part of the piloting of tools for measuring extramural English (EE) habits and vocabulary knowledge among learners in grades 4-6 in Sweden. For the present article, a sample of students in grade $5(\mathrm{~N}=86$; aged 11-12) was used. These students, 39 boys and 47 girls, belonged to six classes at four schools and were taught by five different teachers. All data were analyzed quantitatively, using statistical software (SPSS 19).

In order to measure EE, all participants were asked to fill out a questionnaire and a one-week language diary. The questionnaire aimed not only at mapping the learners' EE habits but also at providing background information about, for example, their mother tongue, experiences of traveling abroad, and self-confidence in relation to English. The language diary (see Appendix 1) measured the learners' engagement in seven given $\mathrm{EE}$ activities: reading books, reading newspapers/ magazines, watching TV, watching films, using the Internet, playing digital games, and listening to music. At the end there was an additional open category where they could list any other English-related activities they had been involved in. The participants were instructed to fill out the diary on a daily basis and note how much time they had spent on each of the activities and also to enter detailed information about titles of books, digital games, and so forth. This method relies on self-report and undoubtedly has flaws regarding reliability (see Greenberg et al., 2010, for an alternative method). For instance, it is difficult to remember exactly how much time one actually spent on particular activities, so the learners were bound to make estimates. In addition, some filled the diary out at home and some in school. 
However, quantitative exploration of our questionnaire data largely corroborated the diary data. For instance, those who according to the questionnaire reported playing digital games regularly reported a higher weekly mean time of gaming in their diaries (2.7 hours) in comparison with those who did not play regularly (2.0 hours). Even though this difference was non-significant $(p>.05)$, the "regular" players also listed more digital game titles in their questionnaires; further, these titles corresponded with titles noted in their diaries. For these reasons, we consider our data reliable. It is clear, though, that classroom-based research entails particular challenges. For instance, if tests have no direct connection with school work, it is far from selfevident that the informants do their utmost in completing them. To avoid such problems, the teachers in our study incorporated all project tasks into their regular teaching. The teachers' impression as well as our own was that the great majority of the students participated to the best of their ability and took the study seriously.

In addition to the questionnaire and the language diary, we piloted a vocabulary test that was based on the validated levels tests available at the Compleat Lexical Tutor homepage (http://www.lextutor.ca/). We designed the test ourselves and included everyday lexical items (i.e., the target vocabulary was not geared towards game lexicon in any way). The test was divided into three parts: (A) Recognition (1,000 word level; i.e., test items were from the 1,000 most frequent English word families), (B) Recognition (2,000 level), and (C) Production (2,000 level). In short, parts (A) and (B) tested receptive and part (C) productive vocabulary knowledge. Part A consisted of 13 statements involving the meaning of a certain lexical item and the student was asked to indicate whether the statement was true $(\mathrm{T})$, not true $(\mathrm{N})$, or whether he or she did not know (X), as in Example 1.

Example 1. Sample item for the Recognition (1000-word level) part of the vocabulary test.

When someone says 'What are you called?', you should say your name. $\quad \square \quad T$

In part $\mathrm{B}$, each question consisted of words in groups of three accompanied by six distractors. The students were asked to pair each of the three words with the most accurate distractor. There were four questions with a total of 12 target items, each constructed as Example 2.

Example 2. Sample item for the Recognition (2000-word level) part of the vocabulary test.

$\begin{array}{llll}1 & \text { original } & & \\ 2 & \text { private } & \text { complete } \\ 3 & \text { royal } & \text { first } \\ 4 & \text { slow } & \text { not public } \\ 5 & \text { sorry } & & \\ 6 & \text { total } & & \end{array}$

The final part $\mathrm{C}$ consisted of 12 sentences, each with a word left out but with the initial two or three letters given:

Example 3. Sample item for the Production (2000-word level) part of the vocabulary test.

1) Plants receive water from the soil through their ro 
This test was piloted in three of the six classes. For practical purposes, students had to complete it at the beginning of grade 6. Finally, the results on the mandatory national test of English (and Swedish) for grade 5 were collected from four classes, which gave us additional data on these specific participants' general English proficiency. Two parts of the test (reading and listening comprehension) were suited for quantitative analysis.

With regard to the language background of the sample, it can be described as homogeneous; only four students had another L1 than Swedish. As for English, the vast majority responded that they consider English important and that it is a school subject they take an interest in. As high a ratio as $82 \%$ stated that they had learned most of the English they know in school, whereas the rest responded that they had mainly learned their English extramurally. In general, the students seemed fairly self-confident: 79\% rated their level of English as 'very good' or 'good'. Another indication of good English self-confidence was revealed when they were asked about their feelings regarding speaking English in the classroom with their teacher or peers: only a handful reported feeling anxious about such tasks.

Some items in the questionnaire were linked to reading habits in Swedish and English. About three out of four students $(73 \%)$ stated that they read books in Swedish regularly (i.e., every day or a few times per week); the rest read less or nothing at all. As for reading English books outside of school, very few did so, which was expected considering the learners' young age.

Even though it is difficult to measure socioeconomic background variables (Hauser, 1994) we tried to do so with the help of questions related to traveling abroad, where students lived, the number of books in the home, and whether they had access to the Internet from home. The responses revealed that the students in our sample seem fairly well off. For instance, most can be considered rather experienced travelers for their age: $87 \%$ had traveled outside the Nordic countries; $34 \%$ had even been outside Europe. The data also showed that those who reported having 50 books or more at home were more widely traveled than those who had less than 50 books $(p<.01)$. If we view traveling abroad and the number of books in the homes as gross indicators of cultural capital in the Bourdieuan sense, the students in our sample seem to come from families with a fairly strong cultural capital. Finally, as for computers in the homes, all had Internet access. This indicates yet again a certain socioeconomic status of our sample.

Admittedly, there are a number of other factors that ideally should be taken into consideration in a study such as the present. Among them are the informants' language aptitude (see, e.g., Carroll, 1981), general cognitive ability (see, e.g., McKay, 2006), and learning styles (see, e.g., Skehan, 1991). As it was not within the scope of the study to examine those variables, certain caution is therefore called for when interpreting the results so as not to overgeneralize their applicability to other groups of learners.

\subsection{Participants' extramural English activities in general and gaming in particular}

As for the participants' engagement in EE activities, the language diary revealed that they spent, on average, 9.4 hours per week in total on such activities. Individual variation was large $(\mathrm{SD}=7.9)$ and the values ranged from nothing to 41.8 hours per week. 
Table 1 Extramural English activities in order of popularity

\begin{tabular}{lll}
\hline \hline Extramural English activity & Mean (hours/week) & SD \\
\hline \hline Playing digital games & 2.6 & 4.3 \\
Watching TV & 2.1 & 2.7 \\
Listening to music & 1.8 & 2.5 \\
Watching films & 1.3 & 2.1 \\
Using the Internet & 1.2 & 2.1 \\
Other activity & .3 & 1.0 \\
Reading books & .1 & 0.2 \\
Reading newspapers/magazines & .0 & 0.1 \\
Total & 9.4 & 7.9 \\
& & \\
\hline \hline
\end{tabular}

The boys spent more time on EE than the girls, 10.6 hours per week as opposed to 8.4 , but this difference was non-significant $(p=.187)$. An analysis of all the various activities for all informants revealed that playing digital games was the most popular one, followed by watching TV, listening to music, watching films and using the Internet (see Table 1).

Using the Internet includes, among other things, visiting various websites, chatting with friends, and e-mail correspondence. Very low values were reported for the reading activities and activities given in the open option. There were no gender-related differences except for playing digital games, where the boys played significantly more (4.4 hours per week) than the girls $(1.1 ; p<.01)$. Data from both the questionnaire and the diary showed that the students played a great variety of games. In the questionnaire, the most frequently mentioned games among the boys were Call of Duty, CounterStrike, and WoW, and among the girls The Sims, Restaurant City, and Zoo Tycoon. All these titles also showed up in the diaries. Altogether, a clear pattern related to gender appeared, where the boys clearly preferred playing online multiplayer role-playing or first-person shooter games and the girls offline single-player simulation games (cf. Kinzie \& Joseph, 2008; Greenberg et al., 2010). A large nationwide survey of media habits among Swedish youth has identified the same pattern (Medierådet, 2010) so in this respect, our sample seems representative of Sweden.

\subsection{Three digital game groups}

As discussed above, both critical concepts in SLA theory and previous empirical studies - although the latter are scarce, especially among young learners - indicate that digital gaming has great potential for language learning. Therefore, the primary purpose of this study was to verify empirically whether the amount of time spent playing digital games and L2 proficiency correlate. Upon examination of the language diary data for playing digital games more carefully, we found that the participants fell into three digital game groups (see Table 2).

The first digital game group consists of 29 students who did not play anything at all ('non-gamers'). In the second group we find 40 students who played some but not very much ('moderate gamers'). This is the largest group and on average they spent 
Table 2 Descriptive statistics for the three digital game groups based on language diary data

\begin{tabular}{|c|c|c|c|c|c|c|}
\hline \multirow[b]{2}{*}{ Digital game group } & \multirow[b]{2}{*}{$\mathrm{N}$} & \multirow[b]{2}{*}{$\%$} & \multicolumn{2}{|c|}{ Time interval (hours/week) } & \multirow[b]{2}{*}{ Mean (hours/week) } & \multirow[b]{2}{*}{ SD } \\
\hline & & & From & To & & \\
\hline 1 (non-gamers) & 29 & 34 & 0 & 0 & 0 & .0 \\
\hline 2 (moderate gamers) & 40 & 46 & $>0$ & $<5$ & 1.5 & 1.4 \\
\hline 3 (frequent gamers) & 17 & 20 & $\geq 5$ & $\leq 23$ & 9.7 & 5.1 \\
\hline Total & 86 & 100 & $\geq 0$ & $\leq 23$ & 2.6 & 4.3 \\
\hline
\end{tabular}

Table 3 Gender distribution in the three digital game groups

\begin{tabular}{|c|c|c|c|c|c|c|}
\hline \multirow[b]{2}{*}{ Digital game group } & \multicolumn{2}{|c|}{ Boys } & \multicolumn{2}{|c|}{ Girls } & \multicolumn{2}{|c|}{ Total } \\
\hline & $\mathrm{N}$ & $\%$ & $\mathrm{~N}$ & $\%$ & $\mathrm{~N}$ & $\%$ \\
\hline 1 (non-gamers) & 9 & 23.1 & 20 & 42.6 & 29 & 33.7 \\
\hline 2 (moderate gamers) & 17 & 43.6 & 23 & 48.9 & 40 & 46.5 \\
\hline 3 (frequent gamers) & 13 & 33.3 & 4 & 8.5 & 17 & 19.8 \\
\hline Total & 39 & 100 & 47 & 100 & 86 & 100 \\
\hline
\end{tabular}

1.5 hours per week $(\mathrm{SD}=1.4)$ on gaming. Finally, the participants who spent five hours or more per week on gaming belong to the third group ('frequent gamers'). There were a total of 17 frequent gamers in our sample with an average gaming time of 9.7 hours $(\mathrm{SD}=5.1)$. The differences in means between the groups were statistically significant (one-way ANOVA; $p=.000$ ). Students from each of the six classes were represented in each of the three digital game groups.

The gender distribution in the digital game groups is shown in Table 3. As can be seen, there are about twice as many girls (20) as boys (9) among the non-gamers. Note also that among the frequent gamers, the vast majority are boys, thirteen compared to only four girls. The highest reported value in that group was 22.7 hours per week.

On the basis of the questionnaire data, the three digital game groups were compared with respect to where they had learned English, i.e., mainly inside or outside of school. Here, group 3 (frequent gamers) had a larger ratio of students claiming to have learned mainly outside of school compared with groups 1 and 2; Chi-2 testing revealed a significant difference between the groups' responses $(p<.01)$. In addition to this comparison, the reading habits for each group were also analyzed. It was found that the proportion of infrequent readers of Swedish books ('once or a few times per month' or 'never or almost never') increased with each digital game group (sig., $p<.01$ ). In other words, group 3 included the largest proportion of infrequent readers $(40 \%)$, group 2 the second largest proportion $(26 \%)$, and group 1 the smallest $(14 \%)$. Finally, one item in the questionnaire asked whether the participants sometimes spoke English in their spare time, for example with friends or family. Here, more than half $(53 \%)$ of the frequent gamers in group 3 responded positively. 
Table 4 Total scores on the vocabulary test for the three digital game groups

\begin{tabular}{|c|c|c|c|c|c|}
\hline $\begin{array}{l}\text { Digital game } \\
\text { group } \\
\text { Total } \mathrm{N} \\
\text { (boys }+ \text { girls) }\end{array}$ & & $\begin{array}{l}\text { Part A } \\
\text { Recognition } \\
1,000 \text { level } \\
\text { Max } 13\end{array}$ & $\begin{array}{l}\text { Part B } \\
\text { Recognition } \\
2,000 \text { level } \\
\text { Max } 12\end{array}$ & $\begin{array}{l}\text { Part C } \\
\text { Production } \\
2,000 \text { level } \\
\text { Max } 12\end{array}$ & $\begin{array}{l}\text { Total } \\
\text { Max } 37\end{array}$ \\
\hline $\begin{array}{l}1 \text { (non-gamers) } \\
N=14 \\
(4+10)\end{array}$ & $\begin{array}{l}\text { Mean } \\
\text { SD }\end{array}$ & $\begin{array}{l}9.1 \\
2.0\end{array}$ & $\begin{array}{l}3.9 \\
2.5\end{array}$ & $\begin{array}{l}3.6 \\
2.5\end{array}$ & $\begin{array}{r}16.6 \\
5.9\end{array}$ \\
\hline $\begin{array}{l}2 \text { (moderate } \\
\text { gamers) }\end{array}$ & Mean & 9.8 & 4.8 & 3.9 & 18.5 \\
\hline $\begin{array}{l}N=26 \\
(9+17)\end{array}$ & SD & 1.9 & 2.9 & 1.9 & 5.7 \\
\hline $\begin{array}{l}3 \text { (frequent gamers) } \\
N=8 \\
(7+1)\end{array}$ & $\begin{array}{l}\text { Mean } \\
\text { SD }\end{array}$ & $\begin{array}{r}10.9 \\
2.3\end{array}$ & $\begin{array}{l}7.6 \\
2.9\end{array}$ & $\begin{array}{l}6.9 \\
3.4\end{array}$ & $\begin{array}{r}25.4 \\
7.6\end{array}$ \\
\hline $\begin{array}{l}\text { Total } \\
\mathrm{N}=48 \\
(20+28)\end{array}$ & $\begin{array}{l}\text { Mean } \\
\text { SD }\end{array}$ & $\begin{array}{l}9.8 \\
2.0\end{array}$ & $\begin{array}{l}5.0 \\
3.0\end{array}$ & $\begin{array}{l}4.3 \\
2.6\end{array}$ & $\begin{array}{r}19.1 \\
6.6\end{array}$ \\
\hline
\end{tabular}

It was also fairly common among the moderate gamers to speak English (42\%), but less so among the non-gamers $(21 \%)$. However, these differences were non-significant $(p>.05)$.

\subsection{Vocabulary knowledge and comprehension skills}

In this section the results for the digital game groups on the vocabulary test (data from three classes) and the national test (data from four classes) are presented. Table 4 reveals the scores for the different parts of the vocabulary test (internal consistency was not computed).

As can be seen in Table 4, the total score improves with each digital game group, so that the frequent gamers (group 3) had a higher total mean score (25.4) than the moderate gamers, who in turn had a higher score (18.5) than the non-gamers (16.6). One-way ANOVA showed that the between-group differences were statistically significant for two parts of the test, part (B) $(p=.012)$ and part $(\mathrm{C})(p=.006)$, as well as for the test as a whole $(p=.007)$. As for part (A), which was the easiest part of the test, the differences were rather small. A comparison of the scores for the boys and the girls showed that the boys outperformed the girls on all three parts of the test and on the test as a whole. The mean total score was 21.3 for the boys and 17.3 for the girls (sig., $p=.025$ ).

With regard to the national test, the scores on both reading and listening comprehension resembled those on vocabulary for all three digital game groups (see Table 5). Again, the scores improved with each digital game group, so that the frequent gamers had a higher total mean score than the moderate gamers, and in turn the moderate gamers had a higher score than the non-gamers, both for reading 
Table 5 Total scores on reading and listening comprehension for the three digital game groups

\begin{tabular}{|c|c|c|c|}
\hline $\begin{array}{l}\text { Digital game group } \\
\text { Total } \mathrm{N} \\
\text { (boys }+ \text { girls) }\end{array}$ & & $\begin{array}{l}\text { Reading } \\
\text { comprehension } \\
\text { Max } 31\end{array}$ & $\begin{array}{l}\text { Listening } \\
\text { Comprehension } \\
\text { Max } 19\end{array}$ \\
\hline $\begin{array}{l}1 \text { (non-gamers) } \\
N=24 \\
(7+17)\end{array}$ & $\begin{array}{l}\text { Mean } \\
\text { SD }\end{array}$ & $\begin{array}{r}21.9 \\
9.3\end{array}$ & $\begin{array}{r}13.2 \\
4.6\end{array}$ \\
\hline $\begin{array}{l}2 \text { (moderate gamers) } \\
\mathrm{N}=30 \\
(11+19)\end{array}$ & $\begin{array}{l}\text { Mean } \\
\text { SD }\end{array}$ & $\begin{array}{r}25.2 \\
4.4\end{array}$ & $\begin{array}{r}14.7 \\
3.4\end{array}$ \\
\hline $\begin{array}{l}3 \text { (frequent gamers) } \\
\mathrm{N}=9 \\
(8+1)\end{array}$ & $\begin{array}{l}\text { Mean } \\
\text { SD }\end{array}$ & $\begin{array}{r}29.1 \\
3.9\end{array}$ & $\begin{array}{r}17.4 \\
2.3\end{array}$ \\
\hline $\begin{array}{l}\text { Total } \\
\mathrm{N}=63 \\
(26+37)\end{array}$ & $\begin{array}{l}\text { Mean } \\
\text { SD }\end{array}$ & $\begin{array}{r}24.5 \\
7.0\end{array}$ & $\begin{array}{r}14.5 \\
4.0\end{array}$ \\
\hline
\end{tabular}

and listening comprehension. Here, the differences between the groups were also statistically significant (ANOVA: reading comprehension $p=.021$; listening comprehension $p=.022$ ). However, there was no gender-related difference for these tests. For reading comprehension, the boys' score was 24.3 and the girls' 24.2 and for listening comprehension 14.9 for the boys as opposed to 14.2 for the girls. In passing, it is noteworthy that the pattern with the frequent gamers scoring highest, followed by moderate and non-gamers, was also found in the scores for the reading comprehension part of the national test in Swedish.

The results highlight what seems to be a trend, namely that there is a positive correlation between L2 proficiency and how much time is spent on playing digital games, at least as measured in the present study. However, since we did not control for other variables, such as prior knowledge of English, aptitude, cognitive level or preferred learning style, other explanations than involvement in gaming are plausible.

\section{Discussion}

We would again like to emphasize the fact that it is important not to overgeneralize the findings in our study, bearing in mind the characteristics of our sample: Swedish $5^{\text {th }}$-graders that are generally well-off. Furthermore, some potentially influential variables were not investigated: language aptitude, general cognitive ability, and learning styles. Neither did we control the learners' level of L2 English proficiency prior to their involvement in extramural English activities such as digital games.

Nevertheless, the study is relevant since it focuses on possible relationships between playing digital games and incidental and informal L2 English learning, which makes it ecologically valid. Among the findings is the identified pattern concerning digital gaming and L2 proficiency. As for the first research question, we 
observed that the results on the vocabulary tests clearly correlated with the amount of time spent gaming in the naturalistic setting of learners' homes. This pattern corroborates the findings in Sundqvist (2009), which also showed that naturalistic gaming among slightly older (9th grade) learners correlated positively with L2 vocabulary (as well as with L2 oral proficiency). In a more experimental setting, Rankin et al. (2006) found that university level students significantly increased their L2 English vocabulary after having played the MMORPG EverQuest 2 for a minimum amount of 16 hours during a 4-week period. Further, Miller and Hegelheimer (2006) and Ranalli (2008) showed that digital gaming is beneficial for L2 vocabulary acquisition, especially if supplemented with additional material, such as vocabulary lists and exercises that can make the vocabulary input more comprehensible. However, it should be pointed out that the learners in those studies were adults, as compared to the youths involved here. Cobb and Horst (2011), in their study on 12- and 13-year-olds, found that word retention was larger two months after than immediately subsequent to game play and that in order for learning to be consolidated, longer periods of playing are necessary. Furthermore, a large lexicon seems to accord with general L2 proficiency (cf. Laufer, 1998), demonstrated in our study by the results on the reading and listening comprehension parts of the national test where, again, there were statistically significant differences between the three digital game groups, with the frequent gamers scoring the highest, followed by the moderate gamers and non-gamers. Thus, despite their young age, there is a pattern that seems related to learners' digital games habits and L2 proficiency.

As for the second research question, another pattern also emerged, namely with regard to gender: the boys outperformed the girls regarding L2 vocabulary. This is in line with previous research in Sweden (Herriman, 1997; Sundqvist, 2009; Sylvén, 2004) and elsewhere (Kuppens, 2010). However, we argue that it is not gender per se that explains this difference in our study, but rather the type of game favored among boys and girls respectively (cf. Greenberg et al., 2010), in combination with the total amount of time invested in game play. This explanation accords with the one given by Herriman (1997) who points out that girls and boys, in general terms, favor different types of text. In the present study we saw that the boys did not only engage in digital gaming significantly more than the girls; they also played other games than the girls. While the girls typically preferred single-player simulation gameş the boys chose first-person shooter or multiplayer games, often MMORPGs, which we consider highly beneficial for L2 acquisition because they provide learners with opportunities for engagement with rich target language input as well as for scaffolded interaction. The girls' favored games seem less favorable in this respect. Notice that results in the same vein were found for learners aged 15-16 in Sundqvist (2009). We hypothesize that if girls were to spend a similar amount of time playing digital games that have similar characteristics in terms of input, opportunities for output, and interaction, they would benefit equally well in terms of L2 proficiency. Even though few such girls can currently be identified, this is something that needs to be investigated further.

Although we found a significant correlation between digital gaming and L2 proficiency as measured in the three tests, it is indeed very difficult to make any claims regarding causality: does the frequency of gaming lead to the high scores on the tests? 
Or do frequent gamers reach high scores because they already have a certain level of proficiency which, in turn, makes it possible for them to play these games? Reinders and Wattana (2010) highlight the need to identify individual differences among learners, where, for instance, cognitive levels may be decisive (cf. deHaan et al., 2010). The frequent gamers in our study had undoubtedly been playing digital games for some time and the fact that they obtained the best scores in our study accords with Cobb and Horst's (2011) claim that longer periods of game play are essential for learning to be consolidated. More in-depth research on this topic using longitudinal naturalistic as well as experimental designs is clearly needed.

A possible explanation for the significant differences between the three digital game groups on the three tests could be factors not included in our research design, such as aptitude, learning style, or socioeconomic background. For instance, it is a well-established fact that the educational level of learners' parents is decisive to school results (Coleman \& Hoffer, 1987). With regard to EE, which is unrelated to school, previous research has shown that it is not connected with socioeconomic background variables, nor even with the educational level of the parents, at least not in a fairly modern and equal society such as Sweden (Sundqvist, 2009). Regarding the digital game groups in the present study, it was not possible to identify any socioeconomic differences between them, even though the group was quite homogeneous in that respect. This may suggest that playing digital games can be an important factor for L2 learning already at an early age, at least for learners from a similar socioeconomic background to those in our study. Furthermore, even though our study does not provide direct evidence, our findings regarding the differences between the boys' and girls' preferred choice of digital games (MMORPGs vs. singleplayer) indicate that the collaborative interaction that takes place between gamers may facilitate L2 acquisition.

Since reading comprehension in one's L1 is linked to that in an L2 (Lundahl, 1998), we found it rather thought provoking that the frequent gamers read less in Swedish in their spare time than the other students while, at the same time, the former students scored the highest on both Swedish and English reading comprehension. A plausible explanation may be that gamers prioritize gaming before reading Swedish books/newspapers/magazines, and in so doing read large quantities of L2 text when, for instance, playing $W o W$. Contrary to doubts raised in Thorne et al. (2009) about the transferability of the communicative competence obtained within gaming to other contexts, we hypothesize that the gamers in our study were able to transfer their gaming L2 knowledge into skills which are highly valued in the assessment of the national tests (cf. the Transfer Principle, Gee, 2007).

\section{Concluding remarks}

In light of the empirically observed prevalence of digital gaming as a pastime activity among the young Swedish learners involved in this study and the deduced potential for L2 acquisition, this study may formulate some implications for the teaching of English as a foreign language. In the emerging new context where L2 learning apparently also occurs outside of the EFL classroom, there are great opportunities for teachers to build on young learners' extramural language experiences and from 
there move on to other language domains that are perhaps not as easily acquired extramurally. In fact, schools are responsible for bridging the gap between students' extramural language activities (or lack thereof) and learning activities intramurally, i.e., in the language classroom (Thorne \& Reinhardt, 2008). For example, by raising learners' awareness of the possible benefits of digital gaming, teachers can help empower gamers and non-gamers alike, for example by "prompting them to seek opportunities to learn to use computers" (Chapelle, 2001:165). Teachers could introduce a language diary as homework, draw information from it about learner preferences, and recommend individualized follow-up L2 activities aimed at expanding target language registers among frequent and moderate players. As for learners who play very little or not at all - or not very productively - teachers could steer them into compensatory activities.

Future research in the field of computer-assisted language learning could examine other types of game and their relationship to a range of aspects of SLA, for instance syntax, written production, and reading comprehension. The potential importance of factors such as language aptitude, learning styles, and motivation is also essential to investigate. There is also an apparent need for longitudinal research in ecologically valid settings where, for instance, a panel of digital gamers is followed and tested at several stages.

\section{Acknowledgement}

We would like to thank the two anonymous reviewers and the editors for valuable comments on drafts of this article.

\section{References}

Carroll, J. B. (1981) Twenty-five years of research on foreign language aptitude. In: Diller, K. C. (ed.), Individual differences and universals in language learning aptitude. Rowley, MA: Newbury House, 83-118.

Chapelle, C. A. (2001) Computer applications in second language acquisition: Foundations for teaching, testing, and research. Cambridge: Cambridge University Press.

Cheung, A. and Harrison, C. (1992) Microcomputer adventure games and second language acquisition: A study of Hong Kong tertiary students. In: Pennington, M. C. and Stevens, V. (eds.), Computers in applied linguistics. Clevedon: Multilingual Matters, 155-178.

Cho, K. and Krashen, S. (1994) Acquisition of vocabulary from the Sweet Valley Kids series: Adult ESL acquisition. Journal of Reading, 37(8): 662-667.

Cobb, T. and Horst, M. (2011) Does Word Coach coach words? CALICO Journal, 28(3): 639-661.

Coleman, J. S. and Hoffer, T. (1987) Public and private schools: The impact of communities. New York, NY: Basic Books.

deHaan, J., Reed, W. M. and Kuwada, K. (2010) The effects of interactivity with a music video game on second language vocabulary recall. Language Learning and Technology, 14(2): 74-94.

Dickey, M. D. (2006) Game design narrative for learning: Appropriating adventure game design narrative devices and techniques for the design of interactive learning environments.

Educational Technology Research \& Development, 54(3): 245-263.

Dörnyei, Z. (2001) Teaching and researching motivation. Harlow: Longman. 
Dörnyei, Z. (2009) The L2 motivational self system. In: Dörnyei, Z. and Ushioda, E. (eds.), Motivation, language identity and the L2 self. Bristol: Multilingual Matters, 9-42.

Ellis, N. (1994) Implicit and explicit language learning - An overview. In: Ellis, N. (ed.), Implicit and explicit learning of languages. London: Academic Press, 1-31.

Ellis, R. (1984) Classroom second language development: A study of classroom interaction and language acquisition. Oxford: Pergamon.

Ellis, R. (1999) Learning a second language through interaction. Philadephia, PA: John Benjamins.

European Commission (2012) Individuals using the Internet for downloading computer or video games or their updates [Data file] http://epp.eurostat.ec.europa.eu/tgm/table.do?tab= table $\&$ init $=1 \&$ language $=$ en $\&$ pcode $=$ tin00120\&plugin $=1$

Forsman, L. (2004). Language, culture and context: Exploring knowledge and attitudes among Finland-Swedish EFL-students with particular focus on extracurricular influence. Lic., Åbo Akademi, Vasa.

Gass, S. and Mackey, A. (2006) Input, interaction and output: An overview. AILA Review, 19: $3-17$.

Gee, J. P. (2007) What video games have to teach us about learning and literacy. Revised and updated edition. New York, NY: Palgrave Macmillan.

Greenberg, B. S., Sherry, J., Lachlan, K., Lucas, K. and Holmstrom, A. (2010) Orientations to video games among gender and age groups. Simulation \& Gaming, 41(2): 238-259.

Hammond, J. and Gibbons, P. (2001) What is scaffolding? In: Hammond, J. (ed.), Scaffolding: Teaching and learning in language and literacy education. Sydney: Primary English Teaching Association, 1-14.

Harteveld, C. and Bekebrede, G. (2011) Learning in single- versus multiplayer games: The more the merrier? Simulation \& Gaming, 42(1): 43-63.

Hauser, R. M. (1994) Measuring socioeconomic status in studies of child development. Child Development, 65(6): 1541-1545.

Herriman, J. (1997) Vocabulary and reading comprehension. Gothenburg: University of Gothenburg.

Joe, A. (1996) Vocabulary learning and speaking activities. English Teaching Forum, 34(1): 2-7.

Kinzie, M. B. and Joseph, D. R. D. (2008) Gender differences in game activity preferences of middle school children: implications for educational game design. Educational Technology Research \& Development, 56(5/6): 643-663.

Krashen, S. D. (1982) Principles and practice in second language acquisition. Oxford: Pergamon.

Kuppens, A. H. (2010) Incidental foreign language acquisition from media exposure. Learning, Media and Technology, 35(1): 65-85.

Lantolf, J. P. and Thorne, S. L. (2008) Sociocultural theory and second language learning. In: VanPatten, B. and Williams, J. (eds.), Theories in second language acquisition. New York, NY: Routledge, 201-224.

Laufer, B. (1992) How much lexis is necessary for reading comprehension? In: Arnaud, P. J. L. and Béjoint, H. (eds.), Vocabulary and applied linguistics. London: Macmillan, 126-132.

Laufer, B. (1998) The development of passive and active vocabulary in a second language: Same or different? Applied Linguistics, 19(2): 255-271.

Laufer, B. and Hulstijn, J. (2001) Incidental vocabulary acquisition in a second language: The construct of task-induced involvement. Applied Linguistics, 22(1): 1-26.

Long, M. H. (1981) Input, interaction and second language acquisition. In: Winitz, H. (ed.), Native language and foreign language acquisition. New York, NY: Annals of the New York Academy of Sciences, 379: 259-278.

Lundahl, B. (1998) Läsa på främmande språk. Lund: Studentlitteratur. 
McKay, P. (2006) Assessing young language learners. Cambridge: Cambridge University Press. Medierådet (2010) Ungar \& Medier 2010. Stockholm: Regeringskansliet.

Miller, M. and Hegelheimer, V. (2006) The SIMs meet ESL. Incorporating authentic computer simulation games into the language classroom. Interactive Technology \& Smart Education, 3(4): 311-328.

Nation, P. (2001) Learning vocabulary in another language. Cambridge: Cambridge University Press.

Nation, P. and Waring, R. (1997) Vocabulary size, text coverage and word lists. In: Schmitt, N. and McCarthy, M. (eds.), Vocabulary. Description, acquisition and pedagogy. Cambridge: Cambridge University Press, 6-19.

Olsson, E. (2011) "Everything I read on the Internet is in English" - On the impact of extramural English on Swedish 16-year-old pupils' writing proficiency. Lic, Gothenburg: University of Gothenburg.

Persson, L. (2011) Language learning in the 21st century: Foreign language acquisition through informal language contact at home. Paper presented at the 21st Annual Conference of the European Second Language Association, EUROSLA 21, Stockholm University, Stockholm, Sweden.

Piirainen-Marsh, A. and Tainio, L. (2009) Other-repetition as a resource for participation in the activity of playing a video game. The Modern Language Journal, 93(2): 153-169.

Ranalli, J. (2008) Learning English with The Sims: exploiting authentic computer simulation games for L2 learning. Computer Assisted Language Learning, 21(5): 441-455.

Rankin, Y. A., Gold, R. and Gooch, B. (2006). 3D role-playing games as language learning tools. Paper presented at the EuroGraphics 2006, Vol. 25, Vienna, Austria, September 4-8, 2006. http://www.thegooch.org/

Reinders, H. and Wattana, S. (2010) Learn English or die: The effects of digital games on interaction and willingness to communicate in a foreign language. Digital Culture and Education, 3(1): 4-28.

Schmidt, R. (1994) Deconstructing consciousness in search of useful definitions for applied linguistics. AILA Review, 11: 11-26.

Schrader, P. G. and McCreery, M. (2008) The acquisition of skill and expertise in massively multiplayer online games. Educational Technology Research \& Development, 56(5/6): $557-574$.

Skehan, P. (1991) Individual differences in second language acquisition. Studies in second language acquisition, 13(2): 275-298.

Spector, J. M. and Ross, S. M. (2008) Special thematic issue on game-based learning. Educational Technology Research \& Development, 56(5/6): 509-510.

Steinkuehler, C. A. and Duncan, S. (2008) Scientific habits of mind in virtual worlds. Journal of Science Education and Technology, 17(6): 530-543.

Stenberg, P. (2011) Den allvarsamma leken: Om World of Warcraft och läckaget. $\mathrm{PhD}$, University of Umeå, Umeå.

Sundqvist, P. (2009) Extramural English matters: Out-of-school English and its impact on Swedish ninth graders' oral proficiency and vocabulary. $\mathrm{PhD}$, Karlstad University Studies, 2009:55, Karlstad.

Sundqvist, P. (2011) A possible path to progress: Out-of-school English language learners in Sweden. In: Benson, P. and Reinders, H. (eds.), Beyond the language classroom. Basingstoke: Palgrave Macmillan, 106-118.

Sundqvist, P., and Sylvén, L. K. (2012) World of VocCraft: Computer games and Swedish learners' L2 vocabulary. In: Reinders, H. (ed.), Computer games in language learning and teaching. Basingstoke: Palgrave Macmillan, 189-208. 
Swain, M. (1995) Three functions of output in second language learning. In: Cook, G. and Seidlhofer, B. (eds.), Principle and practice in applied linguistics: Studies in honour of H. G. Widdowson. Oxford: Oxford University Press, 125-144.

Swain, M. (2000) The output hypothesis and beyond: Mediating acquisition through collaborative dialogue. In: Lantolf, J. P. (ed.), Sociocultural theory and second language learning. Oxford: Oxford University Press, 97-114.

Sylvén, L. K. (2004) Teaching in English or English teaching? On the effects of content and language integrated learning on Swedish learners' incidental vocabulary acquisition. $\mathrm{PhD}$, University of Gothenburg, Gothenburg.

The Entertainment Software Association (2012) Industry facts http://www.theesa.com/facts/ index.asp.

Thorne, S. L. (2008) Transcultural communication in open Internet environments and massively multiplayer online games. In: Magnan, S. S. (ed.), Mediating discourse online. Amsterdam: John Benjamins, 305-327.

Thorne, S. L., Black, R. W. and Sykes, J. M. (2009) Second language use, socialization and learning in Internet interest communities and online gaming. The Modern Language Journal, 93 (Focus Issue): 802-821.

Thorne, S. L. and Reinhardt, J. (2008) "Bridging activities," new media literacies, and advanced foreign language proficiency. CALICO Journal, 25(3): 558-572.

Turgut, Y. and Irgin, P. (2009) Young learners' language learning via computer games. Procedia Social and Behavioral Sciences, 1: 760-764.

Vygotsky, L. S. (1978) Cole, M., John-Steiner, V., Scribner, S. and Souberman, E. (eds.), Mind in Society: The development of higher psychological processes. Cambridge, MA: Harvard University Press.

Waters, J. K. (2007) On a quest for English. T. H. E. Journal, 34(10): 26-32.

Wirman, H. (2007) "I am not a fan, I just play a lot" - If power gamers aren't fans, who are? Paper presented at the Third Digital Games Research Association International Conference (DiGRA 2007): Situated Play, 24-28 September, 2007, Tokyo, Japan. http://www.digra.org/ $\mathrm{dl} / \mathrm{db} / 07311.40368$.pdf

Wood, D. J., Bruner, J. S. and Ross, G. (1976) The role of tutoring in problem solving. Journal of Child Psychiatry and Psychology, 17(2): 89-100.

Wyman, W. (2006) Poll shows Japanese online gaming habits http://www.gamespot.com/news/ poll-shows-japanese-online-gaming-habits-6152949.

Yee, N. and Bailenson, J. (2007) The Proteus Effect: The effect of transformed self-representation on behavior. Human Communication Research, 33(3): 271-290. 
Appendix 1: Language diary (sample page, extramural English, Monday, translated from Swedish).

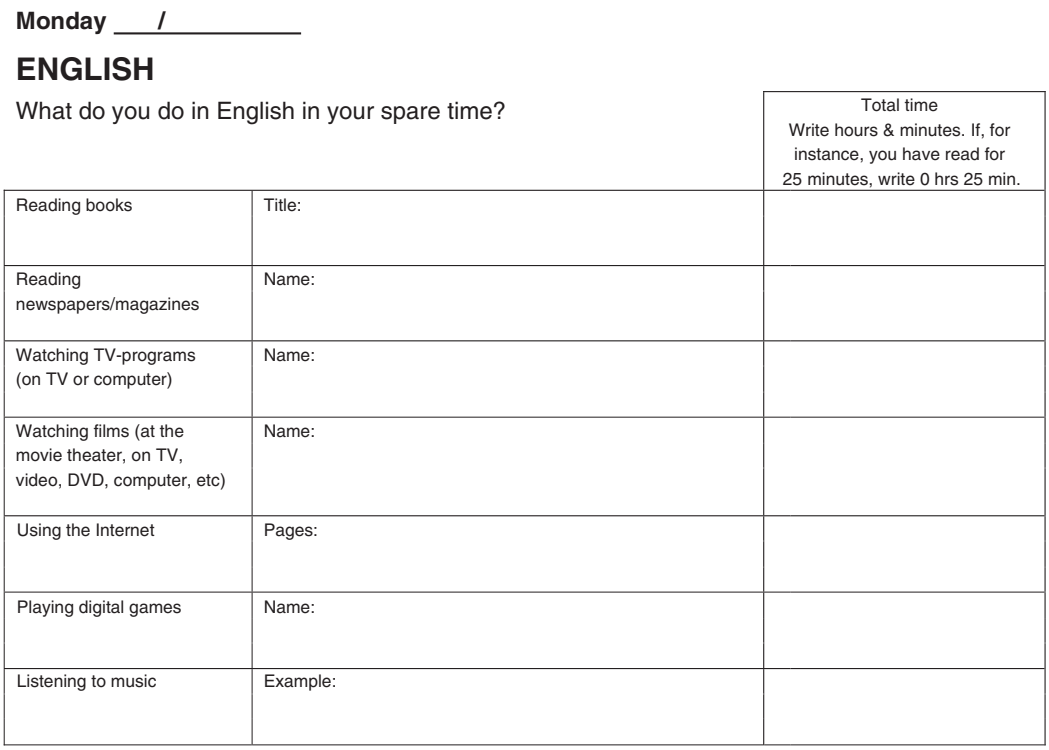

